Article

\title{
'Si vis pacem, para bellum' - the construction of business cooperation in the Swiss machinery industry
}

\author{
Pierre Eichenberger ${ }^{1}$ and Stephanie Ginalski ${ }^{2, *}$ \\ ${ }^{1}$ Forschungsstelle für Sozial- und Wirtschaftsgeschichte, Historisches Seminar, University of \\ Zurich, Rämistrasse 64, 8001 Zurich, Switzerland; ${ }^{2}$ Institute of Political, Historical, and \\ International Studies, University of Lausanne, UNIL-Mouline, Géopolis, Lausanne, Switzerland \\ *Correspondence: stephanie.ginalski@unil.ch
}

\begin{abstract}
This article addresses the historical emergence of business cooperation. We resort to Höpner's (2007) concepts of organization and coordination in order to analyze how firms progressively engaged in Business Interest Associations (BIAs) and interlocking directorates during the first part of the 20th century. Our inquiry is based on a network analysis on large firms of the Swiss machine, electrotechnical and metallurgy (MEM) sector. Our results show that before the First World War, only major firms were promoting coordination and organization through, respectively, interlocking directorates and BIAs. Although many firms were reluctant to cooperate in the first place, interests beyond the firm level (organization) and the economic needs of firms (coordination) had cumulative effects, and most firms progressively engaged in both mechanisms of cooperation from the interwar period. We argue that differentiating between organization and coordination contributes to a more nuanced understanding of the emergence of non-liberal capitalism.
\end{abstract}

Key words: capitalism, coordination, firms, interest groups, networks, Switzerland.

JEL classification: D21 firm behavior, D71 analysis of collective decision-making, (associations), N84 micro-business history Europe 1913-

\section{Introduction}

In 1909, the socialist and trade unionist Robert Grimm (1881-1958) argued that the conditions under which the labor movement had to pursue its objectives had dramatically changed with the creation of strong and well-organized employers' associations. He wrote: 'The times when trade unions could mow down one firm after the other are gone forever. 
Every raid on a firm is henceforth considered as a declaration of war on all employers. Immediately, the employers' federation enters the game and puts all its force to crack down on any strike and to make it ineffective' (Grimm, 1909, p. 57). To confront what the labor leader called 'employers' terrorism' (Ibid., p. 16), he urged his fellow workers to give their support to industrial labor federations.

One year later, Eduard Sulzer-Ziegler (1854-1913), one of the main industrialists of his time, told his fellow employers how dangerous the labor movement had become, as it: 'had declared a war on the entire social order, capitalism in general and the firm in particular' (Sulzer-Ziegler, 1910, p. 61). 'Si vis pacem, para bellum' explained Sulzer-Ziegler: 'If the employers want peace, they must unite; otherwise, if they fail to unite, if they do not get prepared for the war, then will they have the war as a matter of certainty' (Ibid., p. 72).

Labor activism is one reason that pushed people like Sulzer-Ziegler to promote employers' and businessmen's collective action. Influencing the intervention of the state in the economy, stimulating exports, improving standardization, promoting skills among the labor force or regulating competition, have also been important reasons for businessmen to collaborate. Furthermore, firms have a whole range of interactions with one another, including selling and buying products and services, borrowing or lending capital, sharing board members and sealing alliances. Like Martin and Swank (2012, p. 1) have recently argued, 'Employers are social animals and, as such, develop their policy interests in packs'. Firms are nevertheless in competition with one another, and it is anything but obvious that they can prevent the pack from falling apart under the pressure of competition (Galambos, 1966).

Business coordination has been identified as a crucial element, explaining the great variety in the way national economies are organized. A classical issue has been to draw a line between liberal market economies (LMEs) and coordinated market economies (CMEs) (Hall and Soskice, 2001), or liberal and non-liberal types of capitalism (Streeck and Yamamura, 2001). This variety of capitalism (VoC) has been extensively discussed, and remains much debated (Hancké, 2009; Herrigel and Zeitlin, 2010). Recent research has insisted on the necessity to refine the usual dichotomy between CMEs and LMEs. For instance, Höpner (2007) makes a distinction between two dimensions of non-liberal capitalism. According to him, the coordination function of institutions aims at solving firms' collective problems in order to raise profits, while organization 'transcends individual maximization strategies and adjusts them to collective interests beyond maximization' (Höpner, 2007, p. 10). This distinction allows him to differentiate the current process of liberalization between declining coordination and disorganization. In a similar way, Thelen (2014) investigates the relationship between employers' coordination and social inequality. She shows that employers' coordination can persist with declining solidarity, while egalitarian capitalism can overcome declining coordination. Disentangling the different dimensions of non-liberal capitalism allows the authors to highlight different trajectories of liberalization in advanced political economies. We argue that it offers new insights in the analysis of the emergence of non-liberal capitalism as well.

Martin and Swank (2012) provide a useful framework to enable the understanding of the construction of different models of business coordination. They show that political factors were decisive in the emergence of Business Interest Associations (BIAs). However, they mainly investigate the logic of influence of BIAs-i.e. the way they interact with the state and unions - rather than their logic of membership-i.e. the way BIAs interact with firms (Deeg et al., 2013). As a consequence, the authors do not discuss the interaction of BIAs with other forms of coordination, such as interlocking directorates or cartelization. 
In this contribution, we use Höpner's distinction between coordination and organization to complement Martin and Swank's approach of the historical construction of business coordination in Switzerland. The Swiss case is particularly interesting as this country-like Japan-combines coordination 'with features of disorganization' (Höpner, 2007, p. 15). This configuration explains why Switzerland has always been difficult to situate in the classical dichotomy between CMEs and LMEs (Trampusch and Mach, 2011). This article analyzes the emergence of BIAs and interlocking directorates as expressions of organization and coordination. These two major forms of cooperation have received strong attention among researchers. However, the way they interact remains largely unexplored (for an exception, see Windolf and Beyer, 1995, pp. 21-23). We formulate the following research question: when and why did firms engage in either one or both of these channels of cooperation? Answering this question should help us to complement Martin and Swank's study by taking into account interlocking directorates as a form of business coordination. On the other hand, our approach intends to take into account the political factors that contributed to the construction of business coordination, a dimension barely discussed in the literature on interlocking directorates.

In order to answer our research question, we examine how firms in the Swiss leading industrial sector-the machine, electrotechnical and metallurgy (MEM) sector-progressively engaged in BIAs and interlocking directorates. We show how these two institutional arrangements interacted during the first half of the 20th century, the formative period of business cooperation in Switzerland. We argue that coordination and organization-highlighted by the interplay of interlocking directorates and BIAs-followed distinct but cumulative paths and contributed to the growth of a dense MEM business network, which, in turn, decisively shaped the Swiss political economy. After a comprehensive discussion of the theoretical stakes of our research (Sections 2 and 3) and the presentation of method and data (Section 4), we proceed in a chronological manner in order to analyze the different phases of the historical construction of collaboration among MEM elites over time (Section 5).

\section{The historical construction of business cooperation}

Scholars have underlined the importance of taking into account the historical perspective in order to understand the current varieties of capitalism (Thelen and Kume, 2006; Sluyterman, 2015). Similar patterns led, in the late 19th century, to the emergence of institutions that constrained the spread of free markets in Germany and Japan. Both countries, however, developed different paths toward non-liberal capitalism (Streeck 2001). Dore et al. (1999) claim that finance and corporate structures were quite similar in Germany, Japan, Britain and the USA in the 1920s, but the Depression and then the Second World War led to divergent development-intensifying industrial conflicts in the USA and worker-manager cooperation in Germany and Japan.

Martin and Swank (2012) investigate the historical construction of business coordination and show how the 'rules of the game' (the structure of political parties and the form of government) influence the coming of different models of social and economic organization. Again, the interwar period was a decisive period, as the authors highlight that different models of employers' coordination came into being during that period and remained relatively stable for the rest of the century (Ibid., p. 18). 
Hancké (2012) underlines the importance of 'historical and/or institutional precondition' for the emergence of business coordination. However, he shows that interfirm coordination can also emerge in the absence of historical preconditions, as has been the case during the post-1989 reindustrialization in Central and Eastern Europe countries, where states and private associations were weak. This process, described by the author as 'endogeneous coordination'-in opposition to historically induced or externally imposed coordination-shows again that coordination is a dynamic process, rather than a fixed state.

The literature has highlighted the central role of three different institutions in the collective action of firms, namely business associations, corporate networks and banks. First, BIAs 'have a clear and strong coordination function' (Bouwens and Dankers, 2015, p. 105; see also Wood, 2001; Streeck et al., 2006). According to Martin and Swank (2012, p. 16), BIAs encourage firms' coordination among themselves, with labor, and with the government. The authors highlight different models of employers' coordination-macro-corporatist (in Denmark), sectoral (in Germany) and pluralist (in Britain and the USA)—depending on the capacity of peak BIAs (i.e. those claiming to represent all business sectors) to centralize employers' collective action (Ibid., pp. 15-18). According to the authors, peak BIAs were able to centralize employers' coordination in Denmark, but not in Britain and the USA, while sectoral coordination was dominant in Germany. Furthermore, they argue that sectoral and peak BIAs were founded for very different reasons. While 'efforts to export, to control wages, to generate collective skills' explained the development of the former, political factors were decisive for the creation of the latter in order to overcome sectoral heterogeneity (Ibid., p. 35).

BIAs are the most visible form of coordination. However, as stated by Schmitter and Streeck (1999, pp. 9-10): 'If business interests do not (cannot?) find expression through formal associational channels, the focus of attention must shift to other, less visible coordinative arrangements such as ... interlocking corporate directorates ...' (see also Offe and Wiesenthal, 1980, p. 75). Interlocking directorates—defined as the ties among firms that are created by individuals sitting simultaneously on two or more corporate boards-represent a very strong indicator of collaboration between firms and are thus usually denser in CMEs than in LMEs (Windolf and Nollert, 2001; Höpner and Krempel, 2003). In Germany, the corporate network was thus one of the main institutions sustaining German cooperative capitalism, and it grew denser as cartelization increased within the economy (Windolf, 2009). By contrast, interlocking directorates have been perceived in the USA as a threat to competition; interlocks between firms competing in the same markets were prohibited with the Clayton Act of 1914 (Mizruchi, 1996, p. 273). At the least, any interlock is an important channel of communication through which information can be transmitted (Scott, 1985, p. 5). For firms, an interlock may indicate crossshareholding, deals among firms or other forms of cooperation, such as cartels. For the business elite, the configuration of interlocks may also have a broader significance as an indicator of the structure of the capitalist class and of the cohesion within this class (Mizruchi, 1996).

Finally, banks play a crucial role in the corporate governance systems of CMEs. Indeed, financial assets and liabilities in these economies rely mostly on bank deposits and direct loans, providing a more stable financial framework for companies (Vitols, 2001, p. 171). This configuration can be opposed to the one found in LMEs, where firms tend rather to finance themselves through financial markets, which can be accessed more quickly but which are also more volatile (La Porta et al., 1999; Aguilera and Jackson, 2003). Accordingly, the involvement of banks in the financing of companies has an impact on the structure of the corporate network. Indeed, several studies have shown that large banks hold a central 
position in the corporate network of CMEs (e.g. Stokman and Wasseur, 1985), leading to different interpretative models such as the 'bank-control model' according to which bankers sit on the board of directors of the firms they are financing because they want to exert a control over their investment (Scott, 1985).

In order to understand the collective organization of business interests, one should thus take into account the different forms business coordination can take, as they may fulfill different functions. As a case in point, Lanzalaco (2008) distinguishes between capitalists' individual and collective action on the one hand, but also between their actions as employers and as businessmen on the other hand. For the author, these different types of action should not be seen as separated, as they constitute 'an integrated area of research in which market trends, technological innovations, entrepreneurial strategies, industrial relations and political concerns are all interrelated' (Ibid., p. 295; see also Streeck, 1992, p. 80). To address this diversity, we resort to Höpner's (2007) distinction between coordination and organization. According to the author, coordination means that 'institutions help to overcome coordination dilemmas precisely in order to raise profits' (Höpner, 2007, p. 7). In this sense, coordination takes place in the framework of rational choice institutionalism, as institutions solve the coordination problems of self-interested actors. In contrast, the organized capitalism perspective corresponds to Durkheimian sociological institutionalism; in this case, the mission of the firm is 'transcended' by the tensions that exist between the firm and society (Ibid., 2007, pp. 7-9). In other words, while coordination emerges to support firms' interests, organization appears to support collective interests beyond the firm level when being under the pressure of an external force. According to the author, coordination and organization are not conflicting concepts; rather, they refer to different functions that institutions pursue.

\section{Diversity within business coordination: the Swiss case in comparative perspective}

Switzerland combines some aspects typical of CMEs with some 'liberal' (Katzenstein, 1984) or 'conservative' (Mach, 2006) elements more common in LMEs. The Swiss political economy is characterized by a weak central state, weak and fragmented unions, but with a strong coordination among business actors (Trampusch and Mach, 2011, p. 15). As a consequence, Switzerland combines employer coordination with low levels of organization (Höpner, 2007, p. 13).

From a comparative perspective, Swiss BIAs stand out, having a particularly early foundation (Lanzalaco, 2008, p. 305), as well as being especially influential and cohesive (Streeck, 1992, p. 88; Humair et al., 2012). David et al. (2009, p. 28) argue that peak associations 'facilitated a process of self-regulation within the economic world, with the business elite trying to avoid any intervention from outside'. While peak BIAs were very important in political matters, economic and social regulations were often dealt with at the sectoral level (Eichenberger and Mach, 2011, p. 69). Following Martin and Swank's argument on the German case, federalism and the existence of multiple political parties combined in Switzerland to create a 'sectoral driven coordination' of employers (Martin and Swank, 2012, p. 44). The MEM trade association, the Verein schweizerischer MaschinenIndustrieller (VSM), was founded in 1883 in order to help firms of the sector to be represented in commercial exhibitions. The association allowed firms to act collectively in order to defend the sector in domains such as tariff, tax, competition or transport policies. One of 
its main functions was also to represent the sector in the Vorort (the main commercial and industrial peak association), where the different sectors negotiated in order to influence the economic policy of the central state. In reaction to the growing number of strikes at the turn of the century, in 1905 the VSM created the employer's association, the Arbeitgeberverband schweizerischer Maschinen-Industrieller (ASM), in order to deal with labor market issues of the sector (Gruner, 1988, pp. 813-836). There was thus a clear division of labor between the VSM and the ASM.

The Swiss corporate network has also received strong attention from researchers. Several contributions show the existence of a dense network among the largest firms during the greater part of the 20th century (Schnyder et al., 2005; for the MEM sector, Ginalski, 2015), which has been perceived as an expression of the coordinated dimension of the Swiss economy. Schnyder et al. (2005) show that this network was constituted progressively during the first half of the 20th century; they also highlight the central position of the banks (see also Rusterholz, 1985; Nollert, 1998; Ginalski et al., 2014). In this sense, Switzerland was similar to other continental European countries such as Germany, Austria and the Netherlands (Stokman and Wasseur, 1985).

The above-mentioned studies focus either on BIAs or on interlocks, and thus do not investigate how both institutions of coordination interacted. One exception is the contribution of David et al. (2009), which shows that Swiss business elites relied on a dense network of coordination based on interlocking directorates and peak BIAs. However, their study does not integrate sectoral BIAs. In the context of the 'sectoral driven coordination' in Switzerland, investigating the specific role of sectoral BIAs should be placed high on the research agenda.

Relying on Höpner's (2007) distinction between coordination and organization, we investigate the reasons that lead firms to engage in different forms of collaboration. In a theoretical perspective, the different institutions of cooperation (here we use the term cooperation in a 'neutral' way to express coordination and/or organization) fulfill different functions. Interlocks, and relations to banks through interlocks, respond to necessities regarding corporate governance and interfirm relations. In this regard, interlocks can fulfill similar functions to cartelization, which is another way for firms to regulate competition. Trade associations contribute to collective goods regarding the product market, such as technical standardization or the regulation of competition. They also enable business to influence political authorities. Finally, employers' associations are responsible for countering labor mobilization and maintaining favorable conditions regarding industrial relations or vocational training.

Following Höpner's argument, interlocks—and cartels—are institutions of coordination, as they primarily support firms' interests in order to raise profits. In that sense, coordination can be referred to as the economic function of cooperation identified by the $\mathrm{VoC}$ and interlocks literature. Respectively, employers' associations fully correspond to Höpner's concept of organization, as they support collective interests beyond the firm level and are induced under the pressure of an external force (the labor movement, for example). Finally, trade associations are located somehow in the middle, i.e. between coordination and organization, as they aim at improving firms' efficiency, as well as defending their interest in the political arena.

Different configurations of cooperation among firms are then possible (see Figure 1): through interlocks and both types of BIAs (1), through interlocks and employers' 


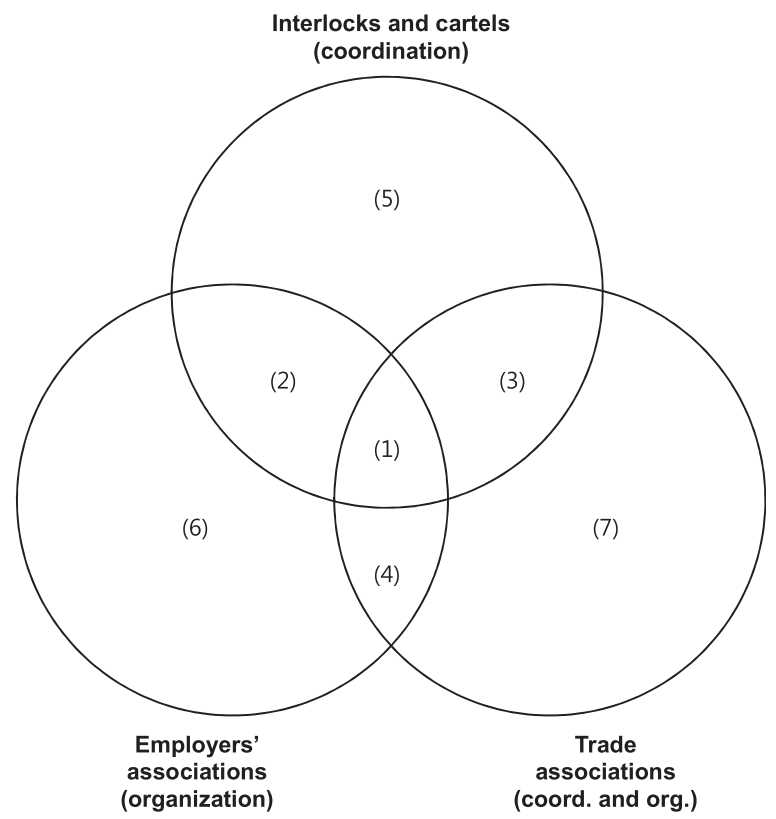

Figure 1: Potential configurations of coordination and organization.

associations (2), through interlocks and trade associations (3), through employers' associations and trade associations (4), through interlocks only (5), through employers' associations only (6) or through trade associations only (7). Accordingly, each configuration corresponds to different degrees of coordination and/or organization. For example, configuration (1) corresponds to the strongest form of coordination and organization, (5) means coordination only and (6) corresponds to organization only.

\section{Method and data}

We apply the above model to investigate how trade and employers' associations and interlocks interacted in the historical construction of business cooperation in Switzerland. We focus on the MEM sector, which became, during the interwar period, the largest industrial employer and exporter of Switzerland (Billeter, 1985). We use a sample of 35 large MEM ${ }^{1}$ companies for three benchmarks across the period we are interested in: 1910 (before the

1 Accu Oerlikon, Ateliers de constructions mécaniques (ACMV), Aluminium Industrie Aktien Gesellschaft (AIAG), Brown, Boveri \& Cie (BBC), Bobst, Bucher, Buss, Société d'exploitation des câbles électriques, à Cortaillod (Cortaillod), Société anonyme de Câbleries et Tréfileries de Cossonay (Cossonay), Dätwyler, Eduard Dubied \& Cie (Dubied), Escher Wyss, Appareillage Gardy SA (Gardy), Georg Fischer, Hasler, Landis \& Gyr, Metallwaren Zug, Metallwerke Dornach, MF Bühler, MF Honegger, Maschinenfabrik Oerlikon (MFO), Oerlikon-Bührle, Paillard, Rieter, Saurer, Schindler, Schlieren, Sécheron, Schweizerischen Industrie-Gesellschaft (SIG), Société genevoise d'instruments de physique (SIP), Schweizerische Lokomotiv- und Maschinenfabrik (SLM), Sulzer, Von Moos, Von Roll and Zellweger Uster. 
First World War), 1937 (interwar period) and 1957 (postwar economic growth). These enterprises were selected thanks to a database on Swiss elites in the 20th century, in which the 110 largest industrial and financial companies have been identified according to different criteria such as the nominal capital, the number of blue-collar workers and the turnover (the database can be consulted at: http://www2.unil.ch/elitessuisses; for more details on the firms' selection, see David et al., 2015, pp. 473-476). First, we selected all the firms that belonged to the MEM sector for the three benchmark years mentioned. In order to have a constant sample for the whole period considered, we then excluded firms that were created after 1910 or that disappeared before 1957 . We also had to put aside a few companies because information was too scarce. In addition to these 35 MEM firms, and because of the central place of banks in the Swiss economy and in the corporate network, we took into account the three largest banks of the country, namely the Schweizerische Kreditanstalt (Crédit Suisse), the Schweizerische Bankgesellschaft (UBS, Bank in Winterthour until 1912) and the Schweizerischer Bankverein (SBS). We identified the board of directors and executive officers of these 38 firms, relying on different published sources such as stock exchange manuals, financial yearbooks, annual reports or monographs.

In addition to these data, we identified for the same three benchmarks members of the executive committees (Vorstand) of the two BIAs of the sector, the VSM and the ASM. An important contribution of our article lies in the use of archival data for both associations and three firms of our sample (Cossonay, Landis \& Gyr and Georg Fischer), which allows us to give a more qualitative interpretation of the cooperative process underway. We chose these three firms because their archives were open to researchers, and because each of them was representative of a distinctive pattern of cooperation.

We then carried out a network analysis (using Pajek software), based on members of firms' boards and associations' committees in order to identify the evolution of the MEM network of cooperation during the first half of the century. We considered there was a link in the network when a person affiliated with one firm or association was sitting at the same time on the board of another firm or association. We could thus identify what we called the MEM business network, focusing on a one-mode network in order to see the links between the firms and the associations. In the following section, we investigate the evolution of the MEM network during the formative phase of business coordination in Switzerland according to the theoretical model proposed in Figure 1 and the different possible configurations between organization and coordination discussed in the theoretical part.

\section{The construction of the Swiss MEM network}

At the beginning of the 20th century, the MEM business network was neither very dense nor cohesive, compared to the following decades. Table 1 shows the main indicators related to the network for the three benchmark years. In 1910, 15 firms were isolated, that is to say none of their directors were sitting on the board of another firm or on the executive committee of the ASM or VSM associations. In 1957, only three enterprises were not integrated into the network. The latter became thus more inclusive, and density-expressing the number of lines in the network as a proportion of the maximum possible number of lines (de Nooy et al., 2005, p. 63)—grew importantly (6.3\% in 1910 and $18.3 \%$ in 1957).

This evolution can be partly explained by two factors. First, the size of the VSM executive committee increased during the period, integrating more firms. Generally speaking, the 
Table 1. MEM business network's main indicators (1910, 1937 and 1957)

\begin{tabular}{llll}
\hline & 1910 & 1937 & 1957 \\
\hline Mean board size of the firms & 7.0 & 8.3 & 9.3 \\
Mean board size of the associations & 15.5 & 16.0 & 20.0 \\
Density (\%) & 6.3 & 12.8 & 18.3 \\
Total number of lines & 49 & 100 & 143 \\
Multiple lines & 11 & 28 & 53 \\
Isolated firms & 15 & 6 & 3 \\
\hline
\end{tabular}

VSM became more representative during that period and reinforced its 'logic of membership' (Schmitter and Streeck, 1999). Second, Table 1 shows that the mean board size of the firms increased during that period, too. This contributed to the fact that interlocking directorates among firms grew denser. Banks contributed for a very large part to this evolution, although MEM firms developed many links with each other. Another interesting feature lies in the fact that multiple lines (i.e. several shared members between two organizations), indicating more cohesive ties (de Nooy et al., 2005, p. 63), also increased considerably during that period. Thus, the MEM business network became clearly more cohesive and inclusive during the first half of the century. In the following pages we investigate the three main stages of this evolution.

In 1910, almost every theoretically possible configuration of coordination/organization indicated in Figure 1 above existed in the MEM business network, except organization through employers' associations only (cf. Figure 2). However, most of the firms were not represented on the executive committee of their BIAs, ${ }^{2}$ nor did they yet share a director with another company or bank (the 15 isolated firms at the top of Figure 2). Several of these firms (ACMV, Bobst, Cortaillod, Dubied, Gardy and Paillard) were established in Frenchspeaking cantons, while the core of the MEM industry lay in the German part of the country. At that time, some of these isolated firms (such as the firms in the canton of Geneva) were members of regional employers' associations. Others were owned and directed by personalities not ready to sacrifice a share of their own individual freedom to any kind of collective action, considering their firm as a 'private matter' (Steinmann, 1958, p. 13). Moreover, most of these companies were at that time rather small and not yet publicly quoted (e.g. Bobst, Bucher); they thus had no large board of directors and fewer opportunities to share a member with another firm. There were indeed quite important differences concerning the board size of companies at the beginning of the century.

In contrast to isolated firms, several companies were represented in both associations' committees and had interlocking directorates with each other and with banks (AIAG, Georg Fischer, BBC, Sulzer and SLM). This small group formed the core of the business network, and we have called it the vanguard of coordination, as it was cumulating forms of coordination with some others of organization. These companies were mainly established in the

2 Some of them were, however, members of ASM and VSM (Buss, Dubied, Schindler and Sécheron), or members of the VSM only (ACMV, Accu Oerlikon, Cossonay, Bucher, Dätwyler, Landis \& Gyr, Metallwerke Dornach, Zellweger Uster). Other firms, mostly from the French-speaking part of Switzerland, were totally absent from both associations (Bobst, Cortaillod, Gardy, Hasler, Paillard). 


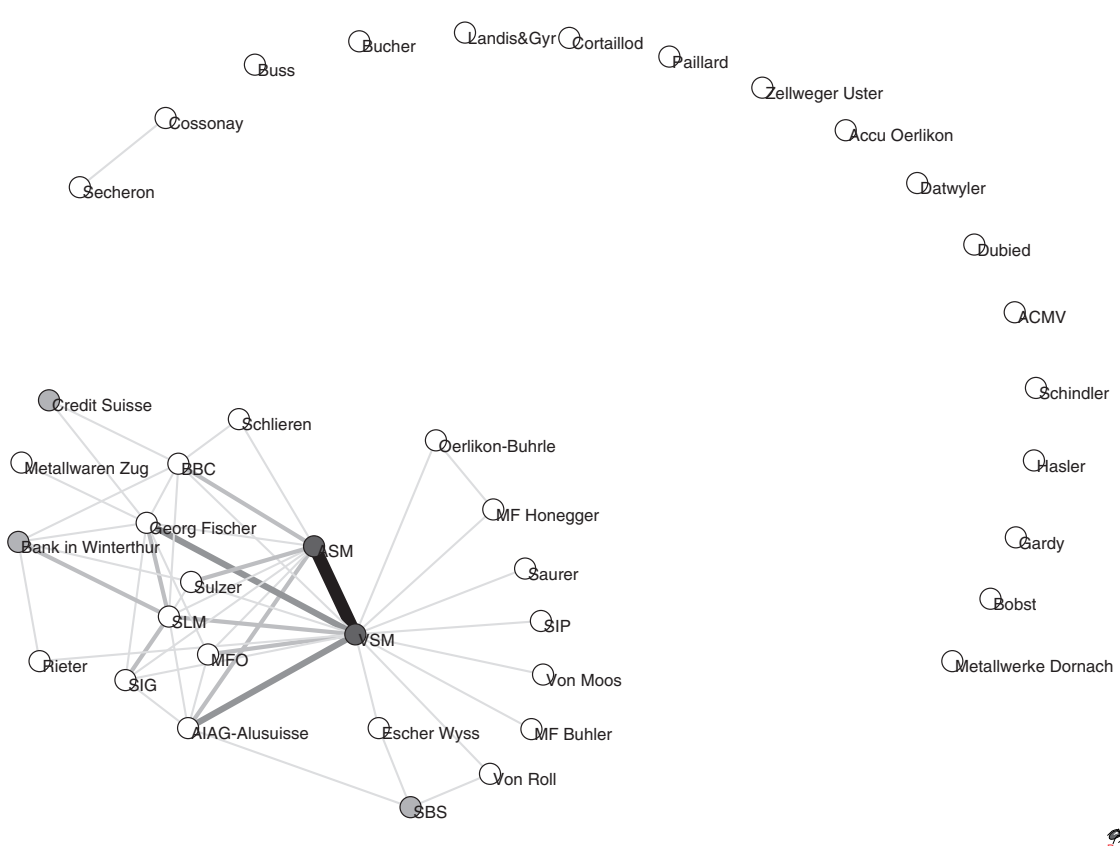

Figure 2: MEM business network in 1910.

Gaillard CACMV
Qhetallwaren Zug

Accu Oerlikon

Schindler

Qon Moos

Bucher

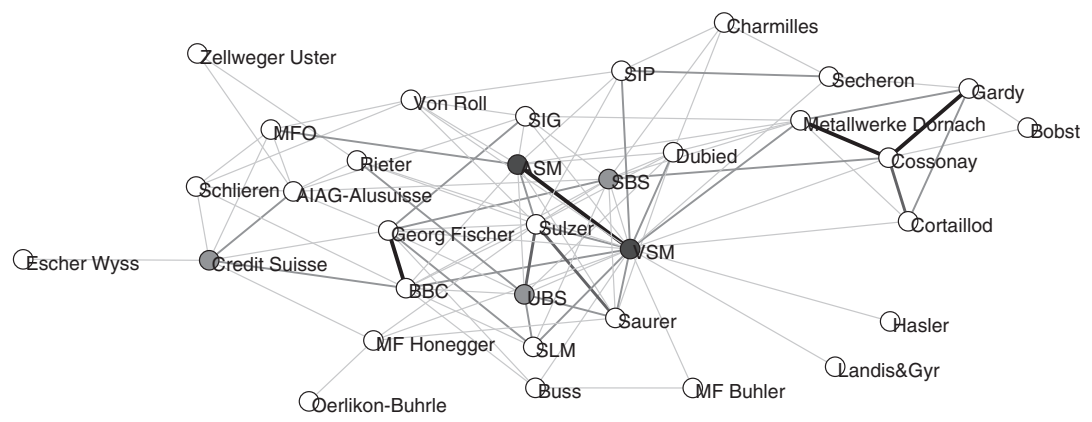

Figure 3: MEM business network in 1937. 
region of Zurich (BBC, Sulzer and SLM), the main industrial center of Switzerland, and Schaffhausen (AIAG and Georg Fischer). At that time, no firm of the French-speaking part was integrated into that core. Moreover, and unlike isolated firms, these firms were among the largest employers of the sector and, generally speaking, were pre-eminent in the MEM industry; for example, at the beginning of the 20th century, almost half of the electrical machines exported by Switzerland were produced by BBC (BBC, 1966, p. 187). As a consequence, these firms were more likely to be represented on the VSM and ASM executive committees and to interlock with other firms, as they already had large boards of directors. The existence of this vanguard of coordination can partly be explained by the existence of important family connections between the people who led MEM firms. Indeed, at that time, family capitalism was the dominant form of corporate governance in the sector (on this issue, see Ginalski, 2013). As a case in point among many other similar examples, in 1910, Gustave Naville-Neher (1848-1929), a former manager of Escher Wyss, chaired the board of AIAG and belonged to both the ASM and VSM executive committees, along with his wife's cousin, Robert Neher (1838-1925), who was the general manager of SIG and a member of the board of Georg Fischer.

A clear will to coordinate and organize business interests emerged during the last decades of the 19th century. Indeed, several people were involved in the creation of the ASM and the VSM, such as Peter-Emil Huber-Werdmüller (1836-1915). The latter was the co-founder of MFO (1876) and AIAG (1888), and was thus a pioneer in the MEM sector. In 1883, he was among the founders of the VSM, promoting active cooperation among firms of the sector in the context of the economic crisis of the 1870s and 1880s, in order to influence the economic policy of the federal state (Humair, 2004, p. 384). One of the main issues at stake was to defend the interest of the MEM industry in the tariff negotiations. In 1905, in the context of increasing labor unrest, Peter-Emil Huber-Werdmüller, together with Gustave NavilleNeher and other directors of BBC, MFO and Sulzer, founded the ASM. In 1910, HuberWerdmüller was the chairman of the board of AIAG and the chairman of both the VSM and the ASM, which he chaired until his death in 1915.

Firms were, however, in a position to be able to choose to become members of both BIAs. Indeed, only 76 firms out of the 111 members of the VSM decided to join the ASM in 1905. ${ }^{3}$ The 1910 business network thus resulted, for a large part, from the initiative of the most important MEM firms that decided to cooperate together; this cooperation being reinforced by the strong ties between the two BIAs and by family connections between the people leading these firms. The very strong ties between the ASM and the VSM illustrated in Figure 2 remained constant throughout the three benchmarks, reflecting the involvement of the same firms - and the same individuals - in both associations and preventing any disagreements between the labor market policies and those concerning the product market.

A third group of companies was only represented on the VSM executive committee and did not share directors with other firms (MF Bühler, Saurer, SIP and Von Moos)—or only with banks (Von Roll and Escher Wyss). We can say that these firms took part in the least constraining form of collective action, mainly in economic domains, and were thus engaged in some forms of coordination and in the least constraining form of organization. Indeed, the VSM, as a trade association, was much less demanding for its members; the association was cheaper and granted broad freedom to firms to act as they wished. On the contrary,

3 Archive of the VSM, 'Protokolle des VSM-Vorstandes 66-140', Vorstand November 17, 1905, p. 14. 
becoming a member of the ASM executive committee implied strong commitment to collective action on matters such as working time, wages, strike insurance groups or recruitment procedures (Gruner, 1988, pp. 813-836). As explained by Gustave Naville-Neher, the ASM was to be set up on different principles to the VSM: 'In order to set up a stronger association, we must accept as members only those firms who engage in submitting themselves to the status ... and give the competencies to the executive committee to impose the decisions made by the association on the members. [The VSM] is not able to do so because it depends on the good will of firms ...,

Finally, some firms did not engage in any form of organization, but did in fact share board members with other firms, such as Cossonay and Sécheron. As we will see, this small component represented, in fact, the embryonic organization of a group of firms established in the French-speaking part of the country.

To sum up, on the eve of the First World War, the large majority of the firms were more or less reluctant to cooperate. Some engaged neither in coordination nor in organization, while some others chose one way or the other (association or interlocking directorates). Only a few firms were actively promoting sectoral coordination and organization. Furthermore, the MEM corporate network relied at that time largely on regional ties, which were constitutive of the formation of the network. For example, in 1909 Georg Fischer decided to elect two leading figures in Schaffhausen onto the board of his firm, Robert Neher and Carl Müller-Landolt, in order to give the greatest place to the area of Schaffhausen but also to the bank of Schaffhausen. ${ }^{5}$

The interwar period corresponded with a sharp increase in the density of the MEM business network: the number of isolated firms decreased from 15 firms in 1910 to 6 in 1937, the simple lines doubled and multiple lines almost tripled (cf. Table 1 above). MEM elites were thus clearly more cohesive in 1937 than in 1910. The most striking evolution consisted of an increase in the number of firms involved in interlocking directorates and BIAs, simultaneously. In short, the vanguard of coordination had gained ground, and the core of firms and actors that constituted this vanguard in 1910 had expanded significantly. Firms already involved in 1910 remained integrated in the core of the network ${ }^{6}$ and were joined by newcomers; Saurer, Dubied, Metallwerke Dornach, SIP and Von Roll, poorly connected in 1910, were sharing directors and holding seats in both associations in 1937 (cf. Figure 3).

In addition to the isolated firms, two companies were, however, still reluctant to cooperate: Landis \& Gyr and Hasler were only represented on the VSM committee. ${ }^{7}$ The former is an interesting example. Although it was publicly quoted, its board of directors was composed of Heinrich Gyr alone, who was not sitting on any other board. Furthermore, the firm

4 Archive of the VSM, 'Protokolle des VSM-Vorstandes 66-140', Vorstand November 17, 1905, p. 10.

5 Georg Fischer historical archive (+GF+HFA), 'Protokolle der 86. Sitzung des VR der GF', March 15, 1909.

6 An exception is AIAG, which temporarily left the ASM and VSM executive committees (but remained as a member of both BIAs) during the interwar period. The firm apparently considered the ASM as too constraining (See Archive of the ASM, 'Protokolle der Vorstands- u. Ausschuss-Sitzungen 1918', Vorstand March 14, 1918, p. 11).

7 An internal report of the ASM indicates that in 1935 a share of about $30 \%$ of the VSM members did not join the ASM; additionally, about the same share of the ASM members were not members of the VSM. See Archive of the ASM, 'Vorstand 10.1 / Ausschuss 10.2', 1937, 'An die Mitglieder des Vorstandes: Verschmelzung von Arbeitgeberverband und Verein', December 7, 1936. 
was not a member of the ASM at all, considering this association too constraining. ${ }^{8}$ It was, however, a member of a regional employers' association (the Arbeitgeberverband von Zug und Umgebung).

Finally, some firms did interact only, or mostly, through interlocks. A meaningful example was the group around the cable manufacturer Cossonay and the cartel it built with Cortaillod, Gardy and Metallwerke Dornach (see Cortat, 2009). This group was very cohesive, shared multiple interfirm ties and was not strongly connected with the VSM and the ASM. This group of enterprises was thus mostly engaged in coordination and not in organization, as their relations were clearly set for production purposes. For example, they discussed the prices of the orders they received in order to find agreement on this issue. Generally speaking, cartelization increased strongly within the economy during the interwar period (Schröter, 1997; Cortat, 2010). In this perspective, Switzerland followed the German way; interlocks grew denser as cartelization increased.

What led to such an increase in cooperation? At least four elements should be mentioned. First, the First World War led to a sharp increase in interventions of the state in the economy, which increased pressure on companies to get organized. Second, the Swiss economy became more fully integrated internally and more independent from external influence (David et al. 2015, p. 127-151). The decrease in the number of foreign directors-and in particular of German directors-after the war contributed, for a large part, to the increasing collaboration among Swiss business elites. Indeed, in 1919, company law was amended; from then on, at least one member of the board of Swiss firms had to be a Swiss citizen, and the majority of board members had to be Swiss residents (Schnyder et al., 2005, p. 28). Moreover, the war and the defeat of Germany also meant the ending of German electromechanical firms' financial investments in Swiss electrotechnical firms, which had been important as a result of insufficient Swiss financing (Segreto, 1992). This contributed to the increase in ties between MEM firms and the three largest banks (coordination), which appears clearly in the 1937 MEM business network. More generally speaking, the rise of the financial sector during and after the First World War led to the expansion of the largest banks' network in Switzerland (Mazbouri et al., 2012) and to the growing of interlocking directorates between the banking and industrial sectors (Schnyder et al., 2005; Ginalski et al., 2014).

Third, the end of the First World War also corresponded with the culminating point of social unrest, marked by the general strike of 1918, which constituted a strong motivation for firms to join the ASM (Billeter, 1985). Thanks to the ASM, MEM firms were able to coordinate decreases of wages at sectoral level in 1921-1922 and 1932, which favored their exports (Müller, 2010). From 1937 onward, the ASM set up collective labor agreements, which regulated labor conditions. The most important one was the 1937 negotiation with unions, leading to the 'labor peace agreement', as it would be later called, which forbade strikes in the sector and increased stability for MEM firms. Here, adhesion of the MEM firms to the ASM was then clearly induced by external pressure.

A last explanation can be found in the increasingly collective answer that the MEM elites gave to the economic challenges of the period, and especially the economic downturn of the 1930s. To give an example, one can mention the creation of the Swiss Association of

8 Archiv für Zeitgeschichte, Zurich, L\&G Archiv, C 108-201, Direktionskonferenz Protokolle, 01.01.3230.12.38, meeting of February 26, 1937 ( $\left.\mathrm{N}^{\circ} 18\right)$. 


\section{Bucher}

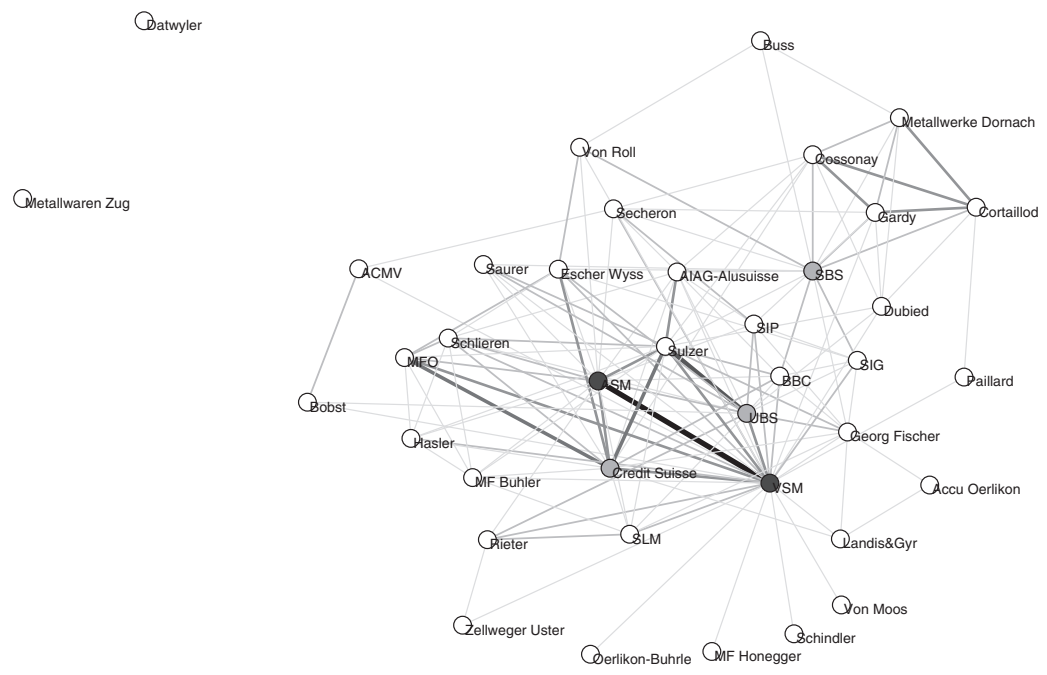

Figure 4: MEM business network in 1957.

Standardization in 1919 by the VSM, which contributed to the setting up of 4500 norms in the industry during the first 50 years of its existence (Ruggaber, 1969, p. 83). In 1934, the VSM was also able to set up a partly public insurance against export risks (Rusterholz, 1986, pp. 247-269).

After the Second World War, the MEM business network was well established and very cohesive; only three firms were not integrated into the network (Bucher, Dätwyler and Metallwaren Zug; cf. Figure 4 above). Some firms were collaborating only through the VSM (MF Honegger, Oerlikon-Bührle, Schindler and Von Moos). Some others favored interlocking directorates as a means to cooperate, a very illustrative example being the cable cartel around Cortaillod, in which firms shared multiple directors (at the top of Figure 4). However, the most striking evolution was the strong development of the vanguard of coordination, following patterns of coordination as well as organization. Most firms were indeed from that point connected through interlocking directorates and BIAs. Moreover, apart from a few firms in the French-speaking part of the country (Cortaillod, Cossonay and Paillard), all firms were members of both associations, even if some of them were not sitting on the executive committee. Cortaillod and Cossonay (both in the cable cartel) were members of a regional employers' association, which was considered by the ASM as an 'action against the solidarity of employers of the [MEM] industry'.

9 Archive of the ASM, 'Protokolle der Vorstands- u. Ausschuss-Sitzungen 1944', Ausschuss December 15, 1944, p. 13. 
Most firms that were still reluctant to cooperate during the interwar period yielded nevertheless to the pressure of the collective action. Indeed, Fernand Turrettini (1882-1951), director of the Geneva-based SIP, mentioned, in a private letter to the ASM, three reasons for his company to join the association: he recognized that the ASM had acted usefully in favor of social peace, he did not want to be considered a 'maverick' anymore and he acknowledged the necessity of joining the association in order to be able to influence its policy. ${ }^{10}$ Again, the war contributed to this increasing cooperation within the MEM sector. BIAs were indeed strongly involved in the economic war mobilization and the VSM and the ASM started to fulfill new tasks in partnership with the state. The VSM was deeply involved in the control of MEM firms' exportations, and it incited them to get organized. So did the ASM; thanks to the fast development of collective labor agreements, which became the cornerstone of labor market management, this association became more and more important and tripled the number of its members between 1938 and 1948.

The Second World War also reinforced the fear of foreign infiltration and the need to unite against it. As stated by Schnyder et al. (2005, p. 33), 'This escalation favored further national control over Swiss firms and accentuated corporate interlocking's function as one of several instruments to achieve this goal.' In this context, the war also contributed to the national integration of the corporate network, overpassing the regional articulation of interlocks that existed in the first place.

From that time on, MEM companies developed more interlocking directorates within their own sector than with other industrial or financial sectors (Ginalski, 2015). We can identify at least four different factors-not excluding one another-that were behind these interfirm ties. First, some interlocks came from cross-shareholdings-and in some cases, reciprocal cross-shareholdings. For example, the multiple links between Sulzer and Saurer in 1937 and 1957 resulted from the reciprocal cross-shareholding concluded between the two firms during the 1920s, and the related exchange of directors (Wipf et al., 2003, pp. 135136). Second, interlocking directorates occurred between firms that were operating in similar markets. At the beginning of the 1940s, AIAG, the main Swiss aluminum producer, decided to undertake aluminum wire drawing. This was obviously perceived as a threat by the cable manufacturer Cossonay, as in 1942, both firms signed an agreement in which AIAG gave up aluminum wire drawing in return for a $20 \%$ stake in Cossonay and a seat on its board of directors. As a consequence, Cossonay gained the quasi-monopoly of aluminum wire drawing. ${ }^{11}$ Third, interlocks also occurred between firms that were operating in different markets, such as AIAG and Sulzer; the former was buying some equipment produced by the latter (Ginalski, 2015, p. 191). Finally, we have to point out the fact that in some cases, MEM firms were only interlinked through bankers, as banks occupied a central place in the corporate network from the interwar period onward. This was the case in 1957 for Georg Fischer and Sulzer, whose common directors were the chairmen of UBS (Fritz Richner) and Crédit Suisse (Ernst Gamper). On this point, Ernst Homberger (1869-1955), chairman of Georg Fischer's board, declared a few years earlier that the appointment of Ernst Gamper

10 Archive of the ASM, 'Vorstand 10.1/Ausschuss 10.2.', 1943, Letter from Ferdinand Turrettini to the ASM, December 7, 1943, pp. 2-3.

11 Archives cantonales vaudoises, PP 632, Société anonyme des câbleries et tréfileries de Cossonay (23), Board of directors January 22, 1942, pp. 183-184. On this issue, see also Cortat (2009, pp. 188189,258 and 401). 
on the board of Sulzer had been a 'bad surprise', as members of Georg Fischer's board should not accept mandates in other foundries, because these mandates represented for the firm 'a serious competition'. ${ }^{12}$ This quote allows us to make two important observations. First, the fact that firms were collaborating more and more after the First World War did not mean that there was no more competition at all. Second, it is important to investigate the nature of the interlock. Here, Sulzer and Georg Fischer were competitors and were not linked together by inside directors. However, the fact that two bankers sat on the board of both firms might have eventually contributed to decrease this competition, even if it was unwanted by the firms in the first place.

As represented in Figure 4 above, the vanguard of coordination had thus managed to impose itself. Coordination and organization had cumulative effects, BIAs and interlocking directorates complementing one another during the post-war economic growth period. A culminating point of this collaboration was the Gentleman's Agreement adopted by the Swiss bankers' association in 1961, by which bankers agreed to refrain from selling Swiss companies' stocks to foreigners. As Etienne and Schnyder (2014) show, this agreement was neither in the interests of the bankers nor imposed by an external force, but corresponded rather to a 'strong solidarity' logic of action among the actors involved. The strong collaboration illustrated in Figure 4 remained very stable until the end of the 1980s. At that point, this system became increasingly called into question by economic globalization, liberalization and shareholder value ideology, which contributed to the decline of the network of coordination (Widmer, 2011; Ginalski, 2015, pp. 154-162).

\section{Conclusion}

Our aim was to investigate how and why firms engaged in collaborative behavior through BIAs and interlocking directorates, and how these two logics interacted. For this purpose, we resorted to Höpner's (2007) distinctive concepts of coordination and organization. As we have shown, cooperation through the trade association (VSM), the employer association (ASM) and interlocking directorates was actively promoted from the beginning of the 20th century-or even from the end of the 19th century-by capitalists of the largest firms, who progressively managed to impose this model on the whole sector. ' $\mathrm{Si}$ vis pacem, para bellum', claimed Eduard Sulzer-Ziegler in 1910, trying to convince capitalists to unite against labor and socialism. In this sense, the construction of business coordination was motivated by political factors-the struggle against socialism, but also a will to prevent an intervention of the state in the business area-thus supporting Martin and Swank's (2012) interpretation of the construction of business interests. However, the 'vanguard of coordination', to which Sulzer-Ziegler belonged, always promoted a diversified and multi-channel cooperation. The ASM was primarily an 'institution of organization' responding to the external pressure led by the increasing power of the labor movement, while interlocking directorates and the VSM were essentially 'institutions of coordination', defending the long-term economic interests of capitalists. As we have shown, many firms were reluctant to cooperate in the first place, favoring individualistic solutions over collective ones; some of them engaged in coordination only, while others privileged organization. Both world wars and the 1930s economic crisis eventually contributed to reinforce a cohesive collective action of the MEM sector. 
During the first half of the 20th century, Swiss capitalists responded thus with growing zeal to Sulzer-Ziegler's injunction and at the end of the 1950s, most MEM firms were engaged in institutions of coordination as well as organization. Our results thus show that both the economic needs of firms and the political pressure must be taken into account in order to explain the emergence of business cooperation.

Interestingly, the sustained adhesion to the employers' association after World War II (although the 'labor peace agreement' had been concluded in 1937) shows that organization can rise from within the sector itself, and not only from external pressure, a result in line with Etienne and Schnyder's (2014) findings. In this sense, business cooperation appears as more than a reactive force, even though the concept of organization also captures Mayntz and Scharpf's (1995) concept of 'shadow of the hierarchy', according to which political elites could always step in. Another important finding of our study lies in the identification of additional factors that pushed industrialists to engage in cooperation. For instance, family ties, as well as regional and linguistic proximity also played an important role. This finding does not contradict other theories of the emergence of coordination discussed in this article, but rather shows that social and cultural factors were also important for the construction of business cooperation.

Coordination and organization vary across time, between sectors, regions and nations (Höpner, 2007, p. 27; Crouch, 2009, p. 93). As noted in the 'Introduction', disentangling the different dimensions of non-liberal capitalism helps to identify different national trajectories toward liberalization. For instance, according to Höpner (2007, pp. 13-16), in the 1990s, Sweden combined a high level of organization with a lower level of coordination, whereas Germany was relatively highly coordinated and organized. Thelen (2014, p. 194f.) shows that in the mid/late 2000s, Sweden maintained a high level of equality in spite of declining coordination, whereas Germany became more unequal, although institutions of coordination were maintained. For Höpner (2007, p. 27), Germany underwent a decline in both organization and coordination, although disorganization went further than the declining capacity to coordinate.

We argue that differentiating between organization and coordination contributes to a more nuanced understanding of the emergence of non-liberal capitalism as well. As the case of the Swiss MEM industry shows, firms followed different trajectories toward business cooperation during the first half of the century. The configuration that dominated during the 30 years of post-war economic growth was thus the result of a complex diachronic process. In order to determine if our findings are limited to the MEM sector or can be applied to the Swiss economy in general, our theoretical model should be tested on other Swiss economic sectors. Moreover, it would be promising to integrate Switzerland in cross-national comparisons. Notably, comparing the formative phases of business cooperation in Sweden and Switzerland respectively-two countries with strong divergence on the relative levels of organization and coordination in the 1990s-could highlight different trajectories in the construction of business cooperation.

\section{Acknowledgments}

We would like to thank Thomas David, Bob Hancké, Rami Kaplan, André Mach, the SER editor and the anonymous reviewers for their very helpful remarks. Previous versions of this paper have been presented in the European Business History Conference, Uppsala 2013, and in the Society for the 
Advancement of Socio-Economics, Chicago 2014. We are grateful to the participants for their comments.

\section{References}

Aguilera, R. and Jackson, G. (2003) 'The Cross-National Diversity of Corporate Governance: Dimensions and Determinants', Academy of Management Review, 28, 447-465.

BBC (1966) Brown Boveri -75 ans: 1891-1966, Baden, Brown Boveri.

Billeter, G. (1985) Le pouvoir patronal: les patrons des grandes entreprises suisses des métaux et des machines (1919-1939), Genève, Droz.

Bouwens, B. and Dankers, J. (2015) 'Competition and Varieties of Coordination'. In Sluyterman, K. (ed.) Varieties of Capitalism and Business History. The Dutch Case, New York and London, Routledge, pp. 103-129.

Cortat, A. (2009) Un cartel parfait. Réseaux, Rひ̄D et profits dans l'industrie suisse des câbles, Neuchâtel, Alphil.

Cortat, A. (ed.) (2010) Contribution à une histoire des cartels en Suisse, Neuchâtel, Alphil.

Crouch, C. (2009) 'Typologies of Capitalism'. In Hancké B. (ed.) Debating Varieties of Capitalism: A Reader, New York, Oxford University Press, pp. 75-94.

David, T., Mach, A., Lüpold, M. and Schnyder, G. (2015) De la 'Forteresse des Alpes' à la valeur actionnariale. Histoire de la gouvernance d'entreprise suisse 1880-2010, Zurich et Genève, Seismo.

David, T., Ginalski, S., Mach, A. and Rebmann, F. (2009) 'Networks of Coordination: Swiss Business Associations as an Intermediary Between Business, Politics and Administration during the 20th Century', Business and Politics, 11, 1-38.

Deeg R., Martinelli R. and Mailand M. (2013) 'Review Symposia. On Cathie Jo Martin and Duane Swank, The Political Construction of Business Interests: Coordination, Growth, and Equality. Cambridge, Cambridge University Press', 2012, Socio-Economic Review, 11, 795-804.

De Nooy, W., Mrvar A. and Batagelj W. (eds) (2005) Exploratory Social Network Analysis with Pajek, New York, Cambridge University Press.

Dore, R., Lazonick W. and O'Sullivan M. (1999) 'Varieties of Capitalism in the Twentieth Century', Oxford Review of Economic Policy, 15, 102-120.

Eichenberger, P. and Mach, A. (2011) 'Organized Capital and Coordinated Market Economy. Swiss Business Interest Associations Between Socioeconomic Regulation and Political Influence'. In Trampusch, C. and Mach, A. (eds) Switzerland in Europe. Continuity and Change in the Swiss Political Economy, London, Routledge, pp. 63-81.

Etienne, J. and Schnyder, G. (2014) 'Logics of Action and Models of Capitalism: Explaining Bottom-Up Non-Liberal Change', Swiss Political Review, 20, 365-387.

Galambos, L. (1966) Competition and Cooperation: The Emergence of a National Trade Association, Baltimore, The Johns Hopkins Press.

Ginalski, S. (2015) Du capitalisme familial au capitalisme financier? Le cas de l'industrie suisse des machines, de l'électrotechnique et de la métallurgie au 20e siècle, Neuchâtel, Alphil-Presses universitaires suisses.

Ginalski, S. (2013) 'Can Families Resist Managerial and Financial Revolutions? Swiss Family Firms in the Twentieth Century', Business History, 55, 981-1000.

Ginalski, S., David, T. and Mach, A. (2014) 'From National Cohesion to Transnationalization: The Changing Role of Banks in the Swiss Company Network (1910-2010)'. In David, T. and Westerhuis, G. (eds) The Power of Corporate Networks: A Comparative and Historical Perspective, London, Routledge, pp. 107-123. 
Grimm R. (1909). La lutte des fédérations patronales en Suisse contre les syndicats ouvriers, Berne, Comité central de la fédération suisse des ouvriers sur métaux.

Gruner, E. (1988) Arbeiterschaft und Wirtschaft in der Schweiz 1880-1914, Vol. 2, Zurich, Chronos.

Hall, P. and Soskice, D. (eds) (2001) Varieties of Capitalism: the Institutional Foundations of Comparative Advantage, Oxford, Oxford University Press.

Hancké, B. (ed.) (2009) Debating Varieties of Capitalism: A Reader, New York, Oxford University Press.

Hancké, B. (2012) 'Endogenous Coordination. Multinational Companies and the Production of Collective Goods in Central and Eastern Europe', Stato e mercato, 2, 203-228.

Herrigel, G. and Zeitlin, J. (2010) 'Alternatives to Varieties of Capitalism', Business History Review, 84, 667-674.

Höpner, M. (2007) Coordination and Organization. The Two Dimensions of Nonliberal Capitalism, MPIfG Discussion Paper 07/12, Cologne, Max Planck Institute for the Study of Societies.

Höpner, M. and Krempel, L. (2003) The Politics of the German Company Network, MPIfG Working Paper 03/9, Cologne, Max Planck Institute for the Study of Societies.

Humair, C. (2004) Développement économique et Etat central 1815-1914. Un siècle de politique donanière suisse au service des élites, Berne/New York, Peter Lang.

Humair, C., Guex, S., Mach, A. and Eichenberger, P. (2012) 'Les organisations patronales suisses entre coordination économique et influence politique: bilan historiographique et pistes de recherche', Vingtième Siècle, Revue d'Histoire, 115, 115-127.

Katzenstein P. (1984) Corporatism and Change. Austria, Switzerland, and the Politics of Industry, Ithaca and London, Cornell University Press.

Lanzalaco, L. (2008) 'Business Interest Associations'. In Jones G. and Zeitlin J. (eds) The Oxford Handbook of Business History, Oxford, Oxford University Press, pp. 293-318.

La Porta, R, Lopez-de-Silanes, F. and Shleifer, A (1999) 'Corporate Ownership around the World', The Journal of Finance, 54, 471-517.

Martin, C. J. and Swank, D. (2012) The Political Construction of Business Interests, Coordination, Growth, and Equality, New York, Cambridge University Press.

Mach A. (2006) La Suisse entre internationalisation et changements politiques internes: la législation sur les cartels et les relations industrielles dans les années 90, Zurich and Chur, Rüegger.

Mayntz, R, and Scharpf, F. (1995) Gesellschaftliche Selbstregelung und politische Steuerung, Frankfurt/New York, Campus.

Mazbouri, M., Guex, S. and Lopez, R. (2012) 'Finanzplatz Schweiz'. In Halbeisen, P., Müller, M. and Veyrassat, B. (eds) Wirtschaftsgeschichte der Schweiz im 20. Jahrhundert, Basel, Schwabe, pp. 467-518.

Mizruchi, M. S. (1996) 'What Do Interlocks Do? An Analysis, Critique, and Assessment of Research on Interlocking Directorates', Annual Review of Sociology, 22, 271-298.

Müller, P. (2010) La Suisse en crise (1929-1936), Lausanne, Antipodes.

Nollert, M. (1998) 'Interlocking Directorates in Switzerland: A Network Analysis', Revue suisse de sociologie, 24, 31-58.

Offe, C. and Wiesenthal, H. (1980) 'Two Logics of Collective Action: Theoretical Notes on Social Class and Organizational Form', Political Power and Social Theory, Vol. 1, Greenwich, CT, JAI Press Inc., pp. 67-115.

Ruggaber, W. (1969) 'Cinquantenaire de l'Association Suisse de Normalisation', VSM/SNV Normen Bulletin, 6, 81-92.

Rusterholz, P. (1985) 'The Banks in the Centre: Integration in Decentralized Switzerland'. In Stokman F. M., Ziegler, R. and Scott, J. (eds) Networks of Corporate Power. A Comparative Analysis of Ten Countries, Cambridge, Polity Press, pp. 131-147. 
Rusterholz, P. (1986) 'Maschinenindustrie und Aussenwirtschaftspolitik: Die Exportrisikogarantie'. In Farago, P. and Kriesi, H. (eds) (1986) Wirtschaftsverbände in der Schweiz, Grüsch, Rüegger, pp. 247-269.

Schröter, H. G. (1997) 'Small European Nations: Cooperative Capitalism in the Twentieth Century'. In Chandler, A. D., Amatori, F. and Hikino, T. (eds) Big Business and the Wealth of Nations, Cambridge, Cambridge University Press, pp. 176-204.

Schmitter, P. and Streeck, W. (1999) The Organization of Business Interests. Studying the Associative Action of Business in Advanced Industrial Societies, MPIfG Discussion Paper 99/1, Cologne, Max Planck Institute for the Study of Societies.

Schnyder, G., Lüpold, M., Mach, A. and David, T. (2005) The Rise and Decline of the Swiss Company Network During the 20th Century, Travaux de Science Politique 22, Lausanne, University of Lausanne.

Scott, J. (1985) 'Theoretical Framework and Research Design'. In Stokman, F. N., Ziegler, R. and Scott, J. (eds) Networks of Corporate Power. A Comparative Analysis of Ten Countries, Cambridge, Polity Press, pp. 1-19.

Segreto, L. (1992) 'Du "Made in Germany" au "Made in Switzerland". Les sociétés financières suisses pour l'industrie électrique dans l'entre-deux-guerres'. In Tédé, M. (ed.) Electricité et électrification dans le monde. Actes du deuxième Colloque international d'histoire de l'électricité, Paris, 3-6 juillet 1990, Paris, PUF, pp. 347-337.

Sluyterman, K. (2015) 'Introduction: Varieties of Capitalism and Business History: The Dutch Case'. In Sluyterman, K. (ed.) Varieties of Capitalism and Business History. The Dutch Case, New York and London, Routledge, 2015, pp. 1-21.

Steinmann, O. (1958) ‘Anfang und Fortgang'. In Geschäftsstelle des Zentralverbandes schweizerischer Arbeitgeber-Organisationen (ed.) Arbeitgeberpolitik gestern und heute. Festschrift zum fünfzigjährigen Bestehen des Zentralverbandes schweizerischer Arbeitgeber-Organisationen 1908-1958, Zürich.

Stokman, F. M. and Wasseur, F. W. (1985) 'National Networks in 1976: A Structural Comparison'. In Stokman, F. M., Ziegler, R. and Scott, J. (eds) Networks of Corporate Power. A Comparative Analysis of Ten Countries, Cambridge, Polity Press, pp. 20-44.

Streeck, W. (1992) 'Interest Heterogeneity and Organizing Capacity: Two Logics of Collective Action?' In Streeck, W. (ed.) Social Institutions and Economic Performance: Studies of Industrial Relations in Advanced Capitalist Economies, London, Sage, pp. 76-104.

Streeck, W. (2001) 'Introduction: Explorations into the Origins of Nonliberal Capitalism in Germany and Japan'. In Streeck, W. and Yamamura, K. (eds) (2001) The Origins of Nonliberal Capitalism, Ithaca and London, Cornell University Press, pp. 1-38

Streeck, W. and Yamamura, K. (eds) (2001) The Origins of Nonliberal Capitalism, Ithaca and London, Cornell University Press.

Streeck W., Grote J., Schneider V. and Visser J. (eds) (2006) Governing Interests: Business Associations Facing Internationalization, London and New York, Routledge, 2006.

Sulzer-Ziegler E. (1910) 'Ueber Arbeitgeber-Verbände', Annual Report of the ASM, Zurich.

Thelen K. (2014) Varieties of Liberalization and the New Politics of Social Solidarity, New York, Cambridge University Press.

Thelen, K. and Kume, I. (2006) Coordination as a Political Problem in Coordinated Market Economies, Governance, 19, 11-42.

Trampusch, C. and Mach, A. (2011) 'The Swiss Political Economy in Comparative Perspective'. In Trampusch, C. and Mach, A (eds) Switzerland in Europe, Continuity and Change in the Swiss Political Economy, London, Routledge, pp. 11-26.

Vitols, S. (2001) 'The Origins of Bank-Based and Market-Based Financial Systems: Germany, Japan and the United States'. In Streeck, W. and Yamamura, K. (eds) The Origins of Nonliberal Capitalism, Ithaca and London, Cornell University Press, pp. 171-199. 
Widmer, F. (2011), 'Institutional Investors, Corporate Elites and the Building of a Market for Corporate Control', Socio-Economic Review, 9, 671-697.

Windolf, P. (2009) 'Coordination and Control in Corporate Networks: United States and Germany in Comparison, 1896-1938', European Sociological Review, 25, 443-457.

Windolf, P. and Beyer, J. (1995) 'Kooperativer Kapitalismus: Unternehmensverflechtungen im internationalen Vergleich', Kölner Zeitschrift für Soziologie und Sozialpsychologie, 47, 1-36.

Windolf, P. and Nollert, M. (2001) 'Institutionen, Interessen, Netzwerke: Unternehmensverflechtung im internationalen Vergleich', Politische Vierteljahresschrif, 42, 51-78.

Wipf, H. U., König, M. and Knoepfli, A. (2003) Saurer: vom Ostschweizer Kleinbetrieb zum internationalen Technologiekonzern, Baden, hier + jetzt.

Wood, S. (2001) 'Business, Government, and Patterns of Labour Market Policy in Britain and the Federal Republic of Germany'. In Hall, P. and Soskice, D. (eds) Varieties of Capitalism: the Institutional Foundations of Comparative Advantage, Oxford, Oxford University Press, pp. 247-274. 